Fagtema Tuberkulose

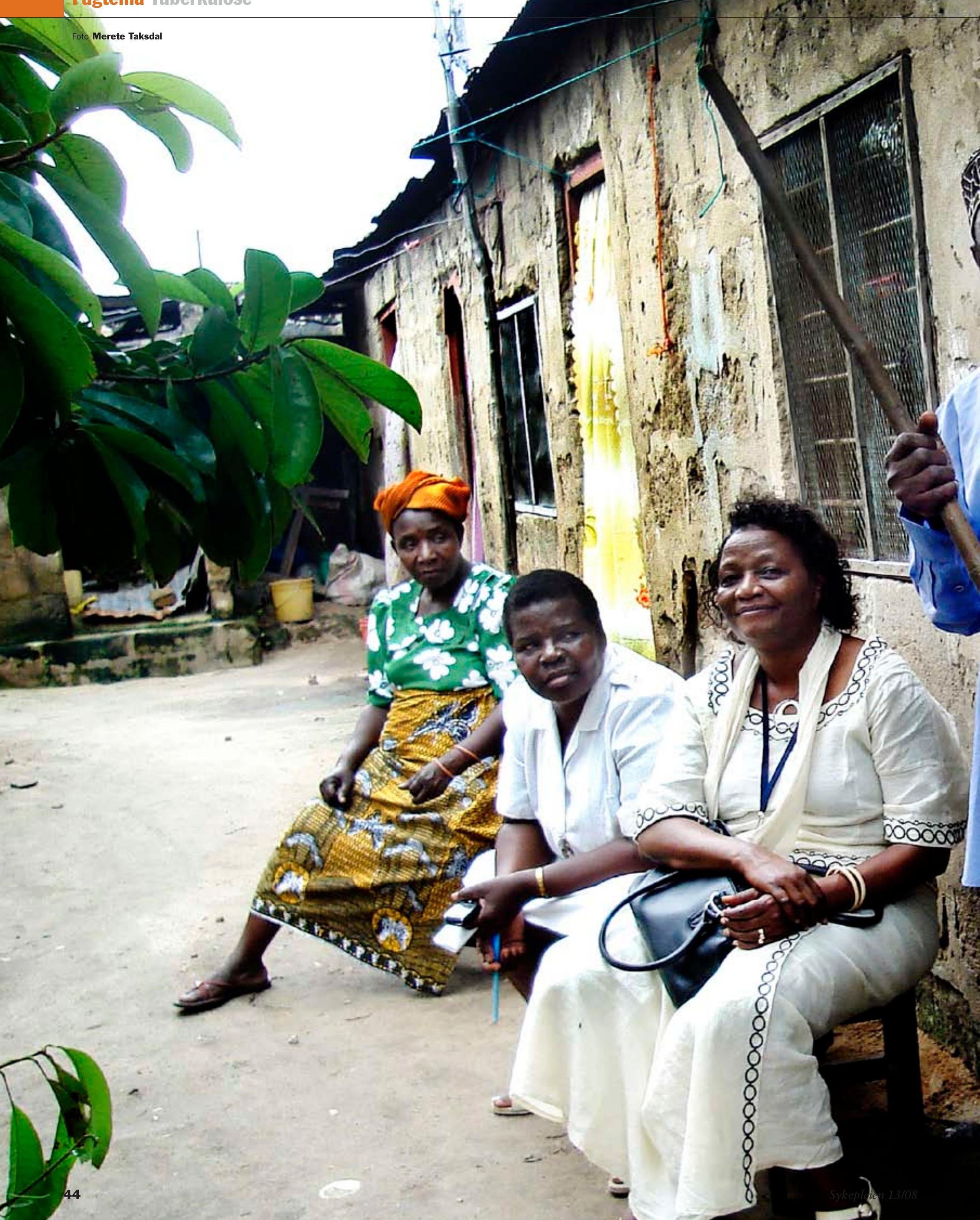




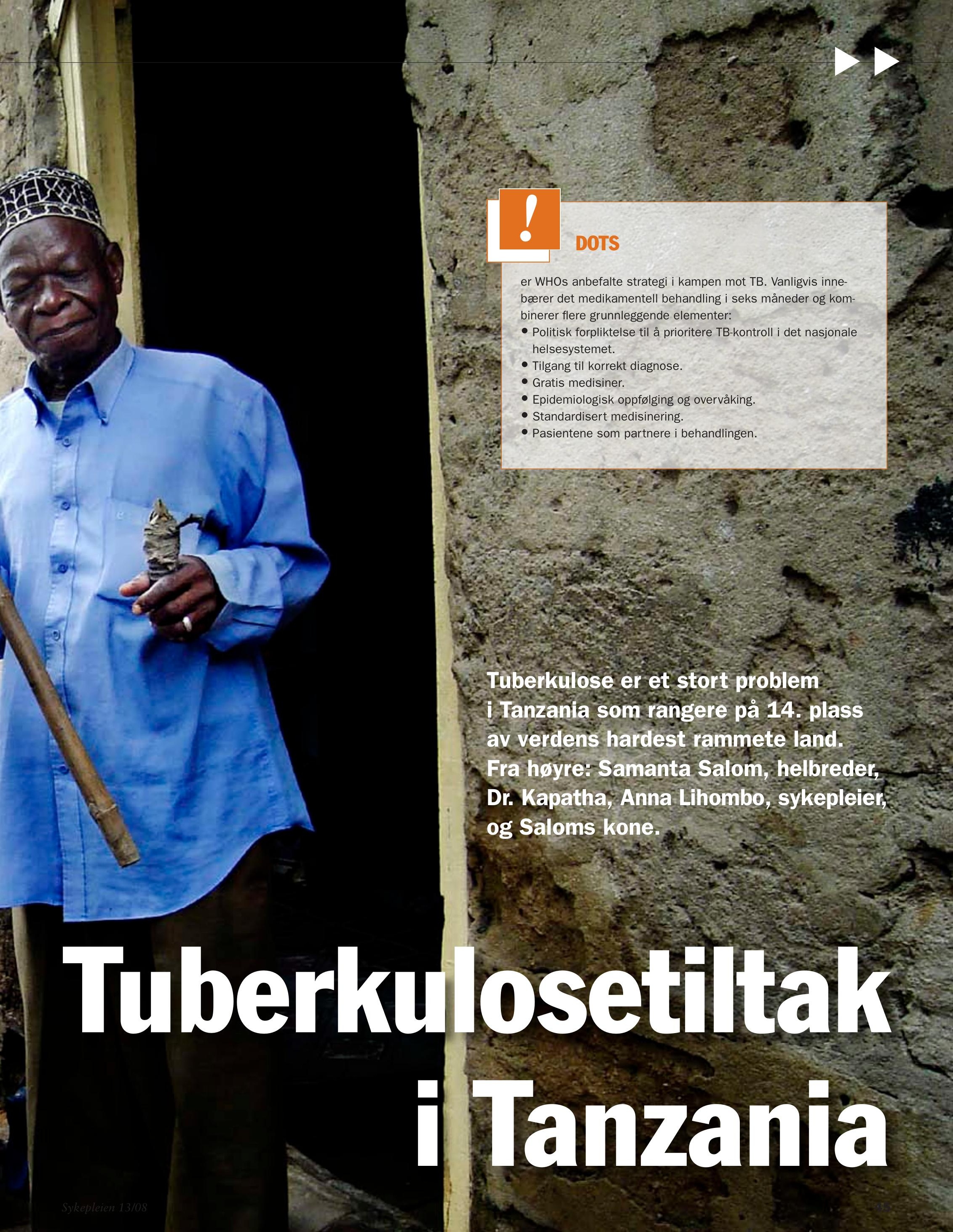




\section{Folk begynner å skjønne at det ikke er en dødsdom å få TB}

\section{www.sykepleien.no}

Les mer og finn
litteraturhenvisninger på
www.sykepleien.no
Søkeord:
Tuberkulose
Tanzania
DOTS
HIV

Dar-es-Salaam er den største byen i Tanzania, en viktig havneby på østkysten ut mot det indiske hav. Cirka en fjerdedel av tuberkulose (TB)-tilfellene i landet finnes her. I denne artikkelen skal dere få et innblikk i TB-arbeidet i Temeke, et distrikt sør i Dar-es-Salaam som omfatter cirka 850000 mennesker. TB-programmet inngår i det offentlige helsevesenet, organisert rundt et sykehus med laboratorium og røntgen, og med klinikker på primærhelsenivå i distriktet. Det samarbeides med private klinikker og frivillige organisasjoner, mange knyttet til kirkesamfunn. Innen TB-programmet har sykepleiere en viktig rolle med å kvalitetssikre behandlingen og sørge for utlevering av de daglige medisinene (1).

\section{Hardt rammet}

Tuberkulose er et svært omfattende folkehelseproblem i Tanzania. Mellom 1977 og 1984 reduserte det nasjonale TB-programmet antall tilfeller i befolkningen med to tredjedeler, og fikk renommé som et av de mest effektive sykdomskontrollprogrammene i verden (2). Deretter seksdoblet TB-tilfellene seg fram mot 2003, og det anslås at minst 60 prosent av økningen skyldes hiv. Landet har en befolkning på i underkant av 40 millioner, prevalensen av TB i befolkningen ligger på 459/100 000 innbyggere i 2006 (3), og rangerer på 14. plass av verdens hardest rammete land. Verdens helseorganisasjon anslår at det var 9,1 millioner nye tilfeller av tuberkulose i verden i 2006. Folkerike land i Asia, som Kina, India og Indonesia har flest tilfeller, men Afrika sør for Sahara er hardest rammet i forhold til folketallet. TB er forårsaket av luftbåren smitte av bakterien «mycobacterium tuberculosis», men omstendighetene det skjer i er helt avgjørende. Fattigdom, underernæring, tettbeboddhet og dårlige levekår skaper vekstvilkår for spredning av tuberkulose. WHO anslår at omtrent en tredjedel av verdens befolkning er smittet, men for de fleste fører det aldri til sykdom. Når immunforsvaret blir svekket, kan imidlertid sykdommen bryte ut. Det er viktig å få TB-diagnose tidligst mulig etter at man er blitt syk, både for å bedre behandlingsresultatet individuelt, og for å hindre smittespredning (4). Ubehandlet TB forårsaker høy dødelighet. Hvis behandling er tilgjengelig er disse dødsfallene unødvendige. TB rammer mange unge mennesker, og i tillegg til problemene dette forårsaker i de enkelte hushold, har det store samfunnsøkonomiske konsekvenser for landene (5).

\section{Temeke}

Temeke er en typisk tilflyttingsforstad der unge fra landsbygda søker lykken. Bydelen har mange tett bebodde hushold, ofte i kummerlige boliger, og befolkningsveksten ligger i underkant av 8 prosent. Det er dårlige sanitærsystemer, tett trafikk, stor arbeidsledighet $\mathrm{og}$ såpass mye nød at mange ikke får dekket sitt daglige kaloribehov. Inntektene kommer i hovedsak fra uformell sektor med handelsfolk, fiskere og ufaglærte som tar strøjobber. Mange langtransportsjåfører losser og lesser last i Temeke, og hiv er vanlig (6). Forventet levealder ligger på 49 år for menn, og 51 for kvinner. Økonomisk ulikhet blant folk er tydelig, med dresskledde menn i nye biler i trafikken, mens gatebarn og tiggere pusser bilvinduer og selger småting mellom kjøretøyene.

Dr.Kapalata har tretti års erfaring som lege og leder TB-programmet i Temeke. Hun sørger for at klinikkene har utstyr og medisiner. I tillegg reiser hun rundt som veileder og «kontrollør» til klinikkene. På en slik rundreise treffer vi sykepleier Angelina Malewo. Hun er ansvarlig sykepleier i TB-programmet på klinikken i Tambukareli. Hun begynte motvillig i jobben i 1998 . Først og fremst var hun redd for å bli smittet selv. Men hun begynte likevel, trives godt og mener det var Guds vilje at hun skulle jobbe med TB pasienter. Angelina anslår at de stiller diagnose på 30-40 nye pasienter i måneden. Det er mye oppmerksomhet rundt TB, sier hun. De har drevet utstrakt informasjon, og dansegruppa til Mukikute (TBpasientorganisasjon som omtales senere i artikkelen) hadde skuespill og dans i noen av landsbyene. Folk begynner å skjønne at det ikke er en dødsdom å få TB, men de utelukker ikke at det er en straff for brudd med tradisjoner eller et umoralsk liv.

\section{Behandlingstilbudet}

Den internasjonalt anerkjente strategien for tuberkulosekontroll kalles DOTS (Directly Observed Treatment Short-Course), og anbefales av Verdens helseorganisasjon. Dersom strategien blir fulgt, kan man behandle TB effektivt og billig, oppnå gode resultater og styrke helsevesenet i fattige land. Ett av kravene i DOTS er at pasientens daglige inntak av medisiner skal være observert. I Temeke er det tilbud om «Community DOT», det vil si at medisinen kan tas hjemme. En slektning eller tidligere TBpasient får oppgaven med å passe på, signerer på skjemaet, og hente medisin for noen uker av gangen. Da behøver ikke pasienten komme til klinikken hver dag. Omtrent halvparten av pasientene foretrekker dette. Sykepleieren drar på hjemmebesøk en til to ganger i måneden, sjekker hvordan det går, og tar spyttprøve etter 2 og 5 måneder av behandlingen. Da kan laboratoriet kontrollere om behandlingen er effektiv. Medisinene de bruker skal gi fullverdig behandling i løpet av seks måneder. Nye diagnostiske utfordringer ligger imidlertid i at TB ikke nødvendigvis kan diagnostiseres med spyttprøver, og at det er vanskelig symptombilde hos hiv+ pasienter. Det er stort sett de som ikke har noen slektninger eller de som bor i nærheten av klinikken som foretrekker å komme dit for å få medisin. Hver pasient har en loggbok på klinikken, og Angelina har laget et arkivsystem med små bøker stilt opp i tomme medikamentesker. Om ettermiddagen gjør de klar neste dags doser ved å klippe opp blisterpakninger til de rette størrelsene. Hvis pasientene ikke kommer for å hente medisiner, 


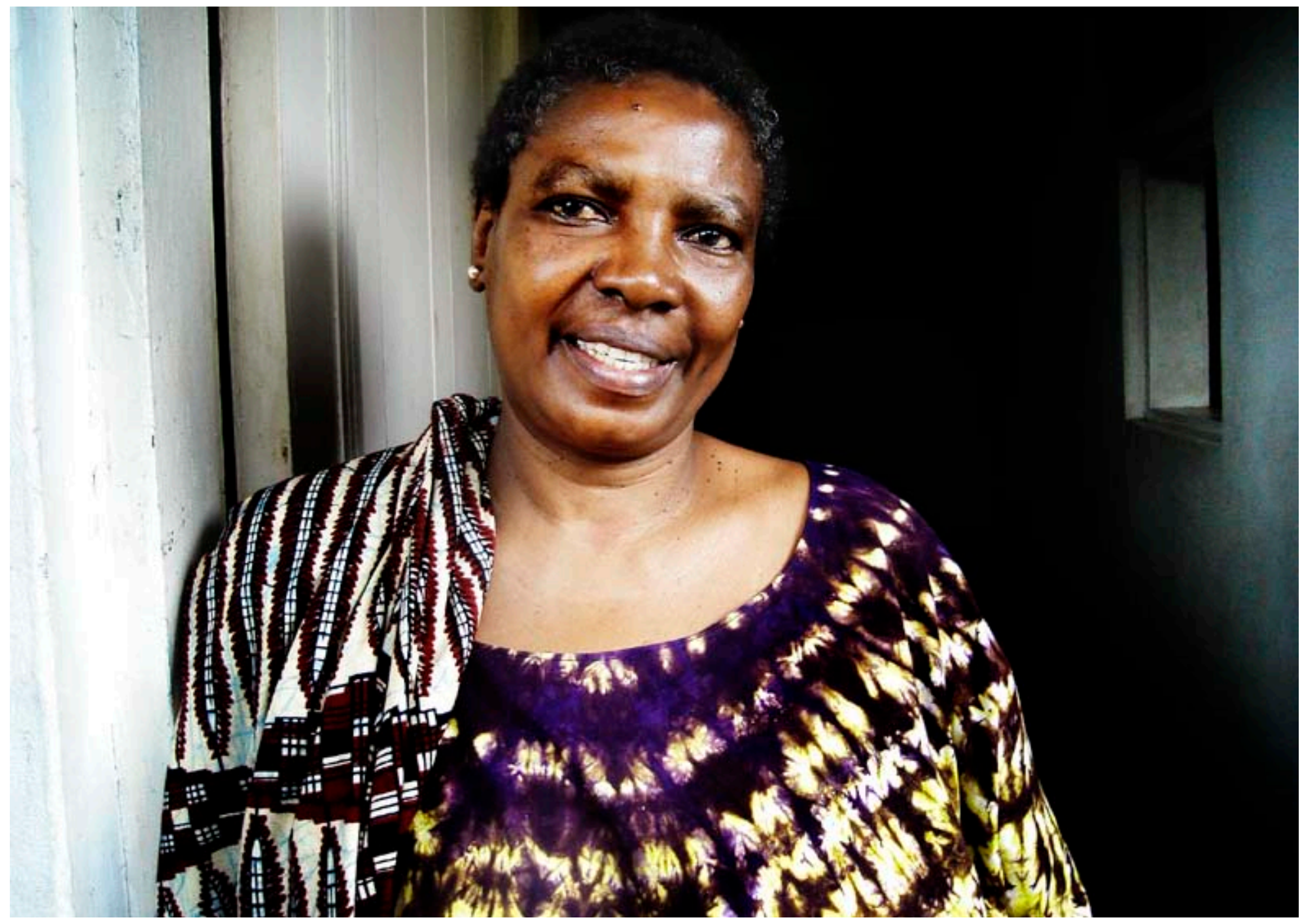

TB-PASIENT: Aisha får behandling hjemme og er på bedringens vei. Foto: Merete Taksdal

blir de sporet opp. Dette er et ledd i å hindre frafall fra behandlingen. Noen ganger er pasientene så svekket at de ikke orker å komme til klinikken, noen føler seg så bra etter to måneder at de slutter med medisiner, og andre flytter uten å si fra. Men de som blir fanget opp igjen blir som regel med på å fullføre behandlingen når de får god informasjon og hjelp til å takle bivirkningene. Det er større frafallsprosent blant de som henter medisiner på klinikken enn de som blir behandlet hjemme. Angelina mener at det kan ha sammenheng med de svake sosiale nettverkene, og at de som har noen til å passe på dem hjemme stiller sterkere. Det er for mange pasienter som dør i løpet av behandlingen, mener $\mathrm{dr}$. Kapalata. Dette kan ha sammenheng med sen diagnose, og det skal forbedres i TB-programmet. Blant annet skal sykepleierne begynne å spørre alle pasienter om de har hostet i mer enn 14 dager, uansett hva de oppsøker helsevesenet for. Håpet er å fange opp flere med smittsom TB tidligere. Når noen kommer med feber midt i malariasesongen er det lett å gi malariamedisin uten ytterligere spørsmål.

\section{Hiv-testing}

TB-pasienter får tilbud om hiv-tester som tas med hurtigtester på klinikken. De hiv-positive blir henvist til sjukehuset for CD4-telling (CD4 eller T-lymfocytter er viktige for kroppens immunforsvar). Men det er en del som aldri drar dit. Angelina sier at de ikke vil bli sett når de drar til sjukehuset, for da skjønner alle at de har hiv. Dessuten verserer det rykter om at kroppen ikke tåler å bli behandlet med medisiner mot TB og hiv samtidig. Derfor ønsker mange av de som har begge infeksjonene å behandle ferdig TB, og deretter gå over på ARV (antiretrovirale medisiner). Angelina sier imidlertid at det går bedre med dem som tar begge deler med en gang når CD4-nivået er lavt (hvis nivået faller under 200 celler/mikroliter blod er det stor fare for dårlig almenntilstand og opportunistiske infeksjoner), fordi de ellers kan bli ytterligere svekket i løpet av den tiden TB-behandlingen tar.

\section{Klinikken}

Klinikken Mgabala i Bagamoya tilhører et annet distrikt i Temeke. Når vi kommer dit er det en endeløs kø av kvinner med småbarn som venter på malariatesting. Det er regntid og vrimler av mygg, så det er viktig å få testet febersyke barn. De skriker i kor etter å ha blitt stukket i fingeren. Det er nesten en 


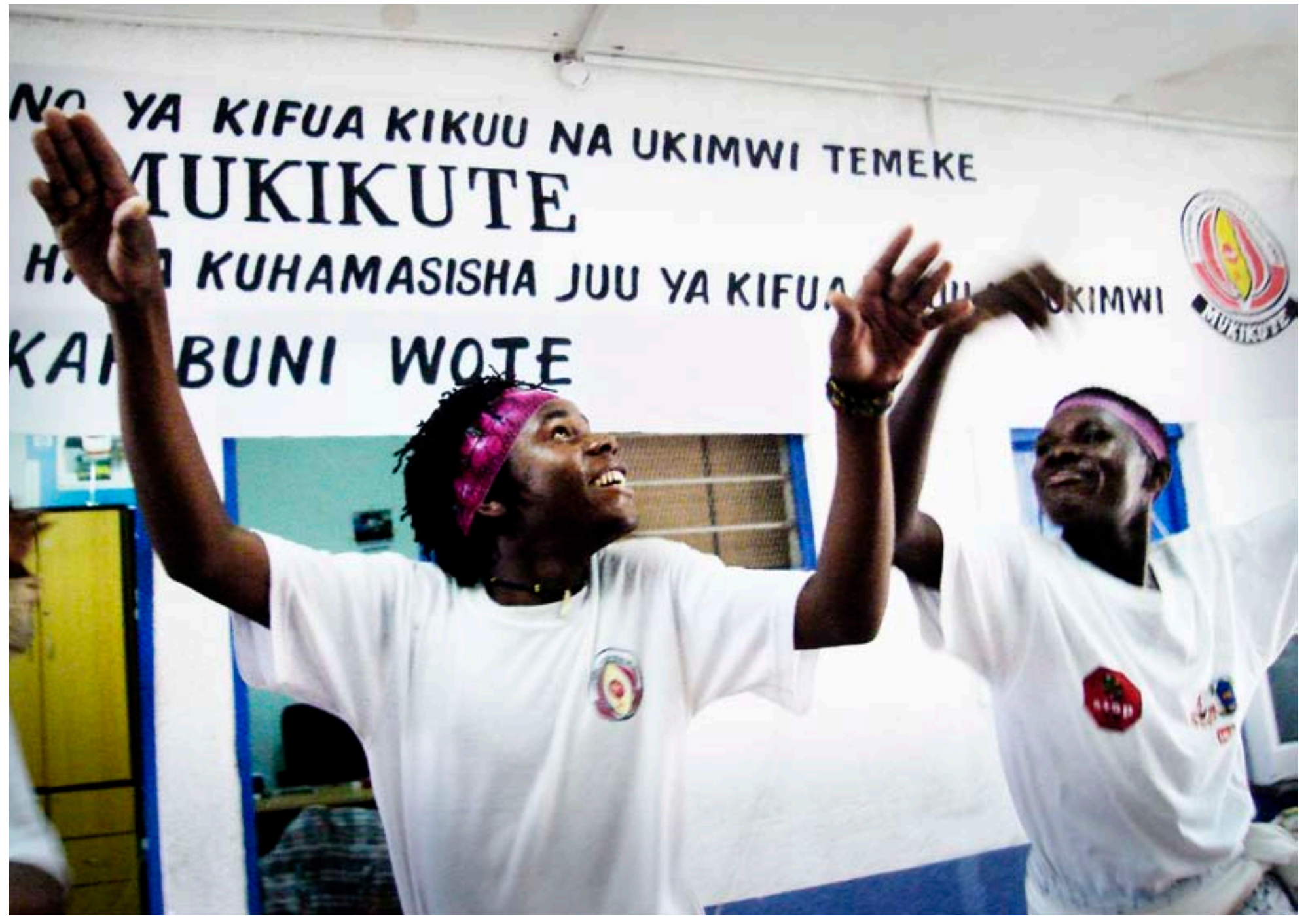

GIR HÅP: Dansegruppa til Mukikute, pasientorganisasjon for TB-pasienter i Tanzania. Foto: Merete Taksdal

frisone å komme til TB-avdelingen, der det er delt ut medisiner til de faste mottakerne jevnt og trutt siden åpningen på morgenen. En dame i tjueårsalderen blir undersøkt, hun er mager og dratt, og andpusten bare av å reise seg opp fra stolen. Hun har feber om kveldene, svetter om natta, og vondt i brystkassa på venstre side. Hun er plaget av hoste. Faren hennes hadde TB for noen år siden, så det er nærliggende for henne å tenke i de baner. Hun blir sendt til laboratoriet for å levere en spyttprøve i et lite beger. Utfra de kliniske tegnene er de sannsynlig at hun har rett i sin antagelse om at hun har TB.

\section{Informasjon}

Sykepleier Scholastica Sagala er nettopp kommet tilbake til klinikken fra et hjemmebesøk. Pasienten er hiv-positiv og har TB, og var både fysisk syk og følelsesmessig nedbrutt over diagnosene. Sykepleieren la vekt på å være åpen og beroligende på første hjemmebesøk, og gi gode råd til søsteren som skulle være ansvarlig for oppfølgingen hjemme. De snakket også mye om ernæring, fordi det er så viktig å få balansert kost, ikke bare «vomfyll». Hun er klar over at folk er fattige, men mener at det ikke behøver å bety at de må spise dyre ting som kjøtt eller egg for å få god ernæring. "Vi har mange næringsrike ting i den tradisjonelle maten", sier hun, men mange fattige spiser nesten bare «ugali». Det er en maisgrøt som man blir mett av, men som ikke inneholder det man trenger av næringsstoffer.

\section{Hjemme hos pasienten}

Scolastica har vært sykepleier i mange år og fikk sin offentlige godkjenning i 1976. Hun har jobbet med mange ting, men begynte åw jobbe med TB-pasienter på sykehuset i Temeke i 1995. I forhold til den gang synes hun folk vet mye mer, og at de har tilgang på bedre hjelp. Forbedringen i helsevesenet

\section{Forbedringen i helse- vesenet har vært enorme de senere årene}

har vært enorme de senere årene, med mye bedre tilgang på utstyr og medisiner. Likevel trives hun godt med å jobbe utenfor sykehus slik hun gjør nå. Først og fremst har det med arbeidsmengden å gjøre. Når de går hjem til folk har de kun den pasienten, og må de ta seg tid til det som trengs for den ene. Hun synes også at det har stor betydning for henne å se hvordan pasientene har det, hun kan observere ting i 
familien og i boligen. Hun mener også at pasienten føler seg veldig ivaretatt ved at noen kommer hjem til dem, det er uvant i et samfunn der man er vant til å kjempe seg til hjelp. Hun legger vekt på lærerfunksjonen hun har i arbeidet med hjemmebasert omsorg. «Alt jeg gjør med pasienten må de pårørende se, slik at de kan følge opp. Heldigvis er det sånn at pasientene vanligvis merker stor bedring i løpet av 2-3 ukers behandling. Vi snakker om smitte også, og det meste av frykten er ubegrunnet. Når folk skjønner at de kan spise sammen, har det mye å si for trivsel og livskvalitet i familien.»

\section{Nærhet til pasienten}

Det som er slitsomt for Scolastica er all reisingen med jobben. Hun må gå mye, eller reise på overfylte busser for å komme til pasientene sine. Men hun verdsetter de tidligere TB-pasientene som stiller opp for å hjelpe. Når folk er redde for å dø, er det av stor psykologisk betydning å møte noen som er helt friske etter behandling. Det motiverer dem til å stå på. Scolastica kommer nærmere den enkelte pasienten fordi hun ser hvordan de bor og snakker mye med dem. Først er de sengeliggende og trenger hjelp til det meste. Men neste gang hun kommer sitter pasienten kanskje i en stol. Og etter noen uker til kommer de henne i møte utenfor huset. Det er inspirerende, og noe av det som gjør at det er en god jobb. «En jobb man blir glad av», sier Scolastica med et smil. Men det er også en påkjenning å være hjemme hos folk i nød og se denne nøden på nært hold. Når pasientene ikke har så mye som en matsmule i huset, er det tungt å forlate dem. Noen er ikke engang sengeliggende, de ligger på gulvet! Ikke så mye som et møbel inne i bølgeblikkskuret de bor i. Ja, man får nøden på nært hold. Om medisinen er gratis, så er det ingen kompensasjon for manglende evne til å jobbe når man er syk. Det kan være katastrofalt for alle i husholdet. «Når man møter pasienter i kø på klinikken vet man egentlig ingenting om dem og livet deres», konkluderer hun.

\section{Hjemme med datteren}

Aisha er en TB-pasient som behandles hjemme på fjerde måneden. Datteren hennes, i slutten av tenårene, er ansvarlig for å følge opp medisineringen. Aisha synes selv at hun er kommet i god form, og tilbringer dagene med rutineaktiviteter. Huset ligger i bakgården til et lite gatekjøkken som er inntektskilden til familien. Da hun ble diagnostisert med TB på sykehuset hadde hun vært syk i lengre tid. Hun hadde brukt hostesaft mot hosten uten bedring, og hun hadde blitt behandlet mot lungebetennelse av en lege på et privat helsesenter. Hun hadde utgifter til røntgen, og det ble sagt at hun hadde væske i pleura. Hun brukte mye penger og tid på all feilbehandlingen inntil hun endelig fikk den riktige diagnosen, som var TB. Hun valgte oppfølging hjemme, for hun var veldig svak, sengelig-

\section{Folk som er syke prover gjerne egen- behandling først}

gende og kunne ikke gå. Nå som hun har fått medisin i flere måneder er hun i fin form, og har til og med god appetitt. Fordelen med å ta medisinene hjemme er ikke minst at hun kan ta dem når hun våkner, og hun slipper å vente i kø på et helsesenter. Det eneste som plager henne er smerter i beina. Datteren synes det var fint å få ansvar for å følge opp morens behandling. Hun skryter også av sykepleier Anna Lihombo som jevnlig kommer innom for å høre hvordan det går. «Det er nesten som å få en venn på besøk, vel så mye som en profesjonell hjelper».

\section{Tradisjonell behandling}

Folk som er syke prøver gjerne egenbehandling først, kjøper medisin på apoteket eller går til tradisjonelle helbredere. Akkurat som Aisha er det mange som har gått bomturer til helsevesenet og brukt mye penger før de får riktig diagnose. I Temeke skal de tradisjonelle helbrederne oppmuntres til å henvise pasienter med TB-symptomer til helsevesenet. Vi traff Samata Salom hjemme i huset der et rom benyttes til praksisen hans. Salom er en erfaren helbreder på godt over 70 år, med hyller fulle av rikholdige remedier fra plante-, mineral- og dyreriket. Han har blitt en nøkkelperson i båndene mellom de tradisjonelle helbrederne og helsevesenet fordi han selv er vellykket behandlet for TB. Salom sier at de forskjellige typene behandling utfyller hverandre, og at de må henvise til de som kan det best. I likhet med 35 andre tradisjonelle helbredere fra landsbyene omkring, har han vært på kurs på sykehuset, og dr. Kapalata håper at de skal se effekten av dette samarbeidet på sikt. Selv om de har forskjellige virkemidler er begge enige $i$ at det er viktig å stoppe spredningen av smittsomme sykdommer. De legger heller ikke skjul på at det er en del motsetninger, og mange pasienter blir møtt med forakt i helsevesenet over at de fortsatt bruker «heksedoktorer». Mange av de tradisjonelle helbrederne erfarer at pasientene kommer til dem i fortvilelse etter at de har oppsøkt helsevesenet mange ganger uten å få riktig behandling.

\section{Mukikute}

Salom er også medlem av Mukikute - den første pasientorganisasjon for TB-pasienter i Tanzania. Organisasjonen er opprettet med støtte fra LHL (Landsforeningen for hjerte- og lungesyke), som selv ble startet av TB-pasienter i Norge for over 60 år siden. Det krever mot å stå offentlig fram, men det er enighet om at pasienter må ha kontroll over sine egne liv hvis man skal klare å stoppe spredningen av TB. Det er viktig at organisasjonen støtter pasientene, slik at de selv tar ansvar for å fullføre behandlingen og at de kan støtte andre i samme situasjon. De må bidra til å videreformidle riktig og nyttig informasjon. Medlemmene i Mukikute har god erfaring med å være åpne om sykdommen for å bekjempe frykt og stigmatisering rundt TB og hiv. De vil vekk fra uforståelig skremselspropaganda og får et positivt budskap fram. De overlevde tuberkulosen! Utvikling av god helsekommunikasjon og pasientorienterte informasjonsbrosjyrer på lokalspråk er viktig for LHL, og Mukikute er viktig for å spre budskapet. Det teller mer enn tusen ord når en tidligere syk TB-pasient kommer tilbake til landsbyen som frisk, og til og med har krefter til å være frontdanser i Mukikutes dansegruppe. Da får folk virkelig tro på at det ikke er en dødsdom å få diagnosen TB. 


\section{Gammel smitte}

\section{holder stand}

\section{Romantiske kunstnere drømte om den, men tuberkulose er en av verdens største mordere.}

Mycobacterium tuberculosis har spredd sykdom i flere tusen år, men ble først identifisert i 1882 av den tyske legen Robert Koch. Med det satte han en vitenskapelig stopper for diskusjonen om tuberkulose skyldtes smitte eller arv.

\section{Dråpe- eller luftsmitte}

Allerede Hippokrates beskrev symptomer på tuberkulose som feber, hoste og avmagring. Bakterien spres når smitteførende dråper eller støvpartikler trenger inn i luftveiene. Det fører i første omgang til en betennelsesaktig reaksjon, som sjelden gir symptomer. Bakteriene kan spres med blodet til hele kroppen, men blir som regel bekjempet av immunforsvaret. Noen klarer likevel å holde seg levende i flere tiår. Enkelte mennesker blir syke det første året etter smitte og får symptomer som dårlig allmenntilstand, feber og tungpustethet. Andre blir først syke etter flere år. De har som regel lungetuberkulose eller tuberkulose andre steder i kroppen.

Bare lungetuberkulose regnes som smittsom. Hos noen danner det seg store kaverner i lungene med puss. Symptomene er gjerne hoste som gradvis forverres og oppspytt med puss og noen ganger blod. Når sykdommen har kommet langt, ses også feber, nattesvette og avmagring.

\section{Vaksine}

I middelalderen økte utbredelsen, på grunn av økende urbanisering og industrialisering. Trangboddhet, dårlig økonomi og sviktende hygiene ga smitten bedre spillerom.

I det 17. og 18. århundre var tuberkulose for eksempel ansvarlig for hvert fjerde dødsfall i Europa. Sykdommen har også blitt kalt «tæring» og «den hvite pesten». Lenge var behandlingen hvile, sol og frisk luft. Etter hvert kom behandlingstilbud som å blåse luft inn i lungene for å få infisert vev til å lukke seg, og kirurgi.

I 1920-årene ble BCG-vaksinen utviklet, og den ble allment akseptert i 1940-årene. I Norge var BCGvaksinen lovpålagt mellom 1947 og 1995. I dag er den et frivillig tilbud i likhet med de andre vaksinene $i$ barnevaksinasjonsprogrammet.

\section{Kunstnernes sykdom}

Mens tuberkulose i dag først og fremst rammer fattige, skapte den mote på 1800-tallet. Mange myter ble spunnet rundt sykdommen. Det hadde nok å gjøre med at de tuberkuløse ble bleke, lyse og vakre. De var ikke fulle av byller og sår, slik ofre for andre sykdommer kunne

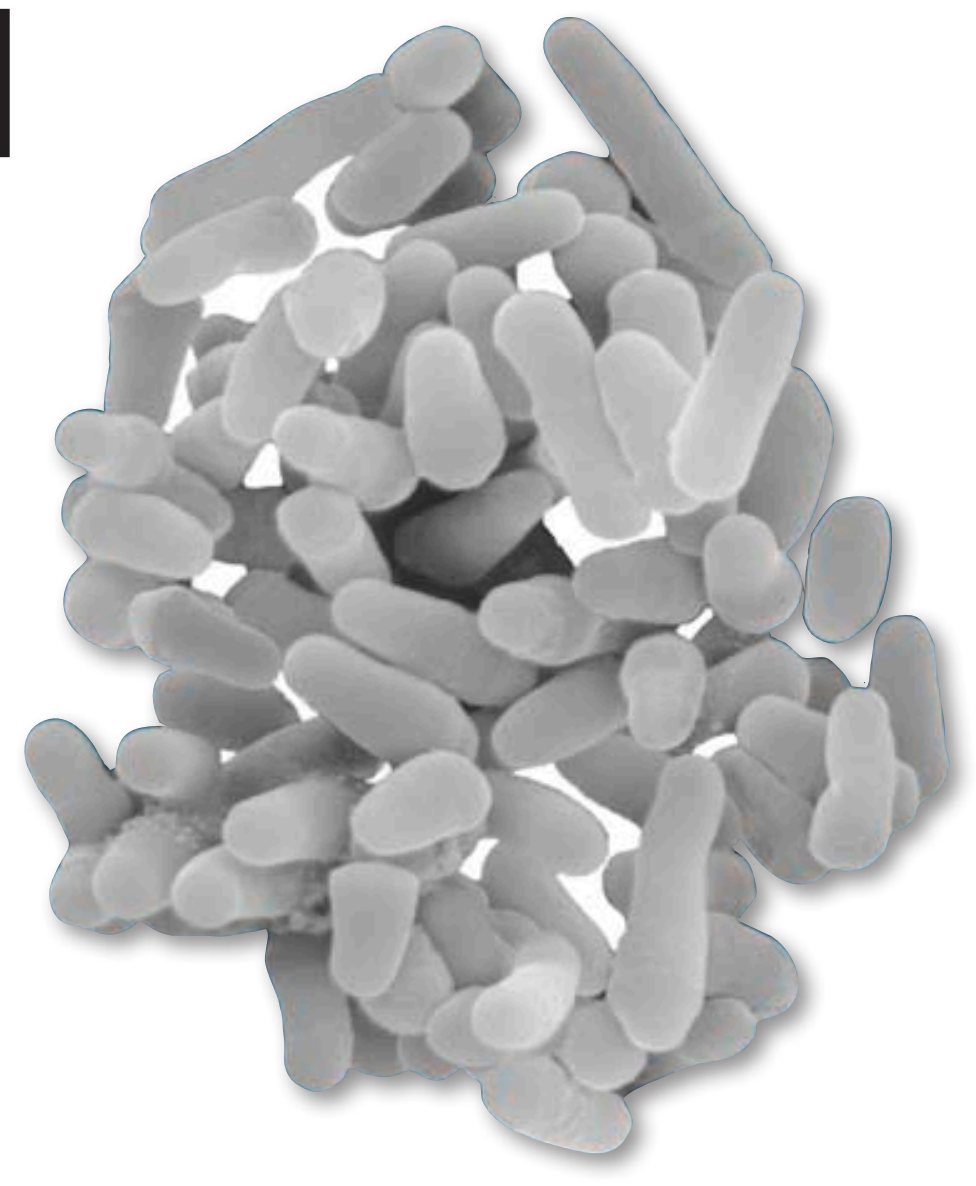

bli. Datidens romantikere hadde forestillinger om at sykdommen var interessant og skapte geniet, og dette geniet var blekt, tandert og melankolsk. Det fantes også forestillinger om at sykdommen «foredlet» menneskene og gjorde dem mer levende.

\section{Kilder:}

Andersen, Bjørg Marit. Patogene bakterier. - diagnostikk, behandling og smittevern. Oslo: Gyldendal, 2001

Folkehelseinstituttet, www.fhi.no Tjade, Trygve. Medisinsk mikrobiologi og infeksjonssykdommer. Bergen: Fagbokforlaget, 2002

Tuft, Guri. Epidemier før aids. Farsottenes kulturhistorie. Oslo: Cappelen, 1989
Den engelske dikteren Lord Byron skal i 1828 ha sett seg i speilet og uttalt: «Jeg ser blek ut.Jeg ville ha likt å dø av tæring». På spørsmål om hvorfor, svarte han: «For da ville alle damene si: Se på stakkars Byron, så interessant han ser ut i døden».

\section{Potente medisiner}

I 1944 kom et medikamentelt gjennombrudd i form av streptomycin. Frem mot 1969 ble det utviklet flere legemidler. I industrialiserte land er dødeligheten av tuberkulose i dag meget lav, mens den i fattige land er svært høy. På verdensbasis regnes tuberkulose for å være den sykdommen som tar flest liv. 


\title{
Krever kontroll
}

\author{
Aldri har det vært så mange tuberkulosesyke i verden som i dag.
}

- Afrika sør for Sahara er hardest rammet av tuberkulose, forteller overlege Karin Rønning ved Seksjon for smittsomme sykdommer på Folkehelseinstituttet.

- Er det områder som står i fare for å bli hardere rammet enn $i$ dag?

- De landene som har høyest forekomst av tuberkulose, er stort sett de landene som har høy forekomst av hiv, økende antall fattige, et helsevesen som har brutt sammen og ustabil tilgang på medisiner, sier hun.

\section{Også Asia}

- Det er ganske høye tuberkulosetall i mindre områder i Asia, men hovedproblemene har de i Afrika sør for Sahara.

- Hva med Russland og ØstEuropa?

- Der er det også problemer med hiv og multiresistens, men ikke av samme omfang som i Afrika.

Anslag fra Verdens helseorganisasjon tilsier at en tredjedel av verdens befolkning er smittet av tuberkulose. 95 prosent av dem bor i lav- eller mellomkostnadsland. 30 prosent får diagnose, halvparten av dem igjen blir helbredet.

Ifølge Rønning har det aldri vært så mange tuberkulosesyke i verden som i dag.

\section{Medisiner}

- Hva er de største utfordringene $i$ forhold til tuberkulose?

- Tilgang på helsevesen og medisiner. Dette dreier seg om fattige land med dårlig utviklede helsesystemer og lav tilgang på kvalifisert personell. Noen har ressurser til å bygge opp bedre systemer, andre prioriterer det ikke. Det er forskjeller landene mellom.

\section{- Har du eksempler?}

- Angola er for eksempel ikke så hardt rammet som andre land sør for Sahara. De har et bedre utviklet helsevesen enn nabolandene, med tilgang på kompetanse og medisiner. Det gjør at situasjonen har gått fra å være ille til å bli litt mindre ille.

\section{Solidaritet}

- Gjør Norge noe internasjonalt for a forebygge tuberkulose?

- Norge deltar i ulike prosjekter i Baltikum og enkelte land i det tidligere Sovjetunionen. Dessuten deltar vi i ulike internasjonale utviklings- og vaksineprosjekter. Det som har vist seg veldig viktig er politisk vilje. Det handler om å bygge opp registre over smittede og å følge opp behandlingen de får.

I Norge er tuberkulose en meldingspliktig sykdom. Alle som blir syke må følge direkte observert behandling (dot). Det innebærer at hver eneste pille som tas de seks månedene behandlingen varer, skal deles ut av helsepersonell, for eksempel en hjemmesykepleier. At pillen inntas og svelges blir observert og dokumentert. Det er ikke aktuelt å få utdelt sin egen pilleeske.

- Dette gjennomfører vi helt konsekvent, sier Karin Rønning.

- Det er del av en internasjonal solidaritet. Slik vi mener andre bør gjøre dette, skal vi også gjøre selv.

Det er viktig også for å hindre utvikling av multiresistens i Norge. Å behandle tuberkulose er besværlig og det er en fare for at behandlingen blir avbrutt.

\section{Kontroll}

- Vil Norges tuberkulosetall holde seg lave?

- De vil svinge i takt med antall flyktninger, asylsøkere og arbeidsinnvandrere. Så lenge vi har høy innvandring fra land med høy forekomst av tuberkulose, vil tallene øke. Skulle det komme færre, vil de synke.
I dag er det nesten ingen som blir smittet av tuberkulose i Norge. I hovedsak er det to grupper som blir syke: Eldre mennesker, som er født i Norge og som ble smittet som barn. De kan få reaktivert tuberkulose. Og så er det yngre utenlandsfødte som er smittet i sitt opprinnelige hjemland, og som utvikler sykdom når de kommer til Norge.

Andelen norskfødte som får tuberkulose vil synke, ettersom de som er smittet som barn etter hvert vil dø ut.

- Vil det ikke vere noen om 25 år?
- Kanskje noen hiv-positive og noen som har oppholdt seg over lengre perioder i områder med høy risiko for smitte.

- Vil Norge klare å kontrollere situasjonen?

- Vi legger vekt på å kontrollere risikogrupper. Det gjør vi av to grunner: For å finne de som er syke, så vi kan starte behandling. Og for å finne de som ikke er syke, men har latent smitte. Da kan vi vurdere forebyggende behandling, forteller Karin Rønning.

\section{Planer om ny seng? Se vårt utvalg av sykehus- og institusjons- senger først!}

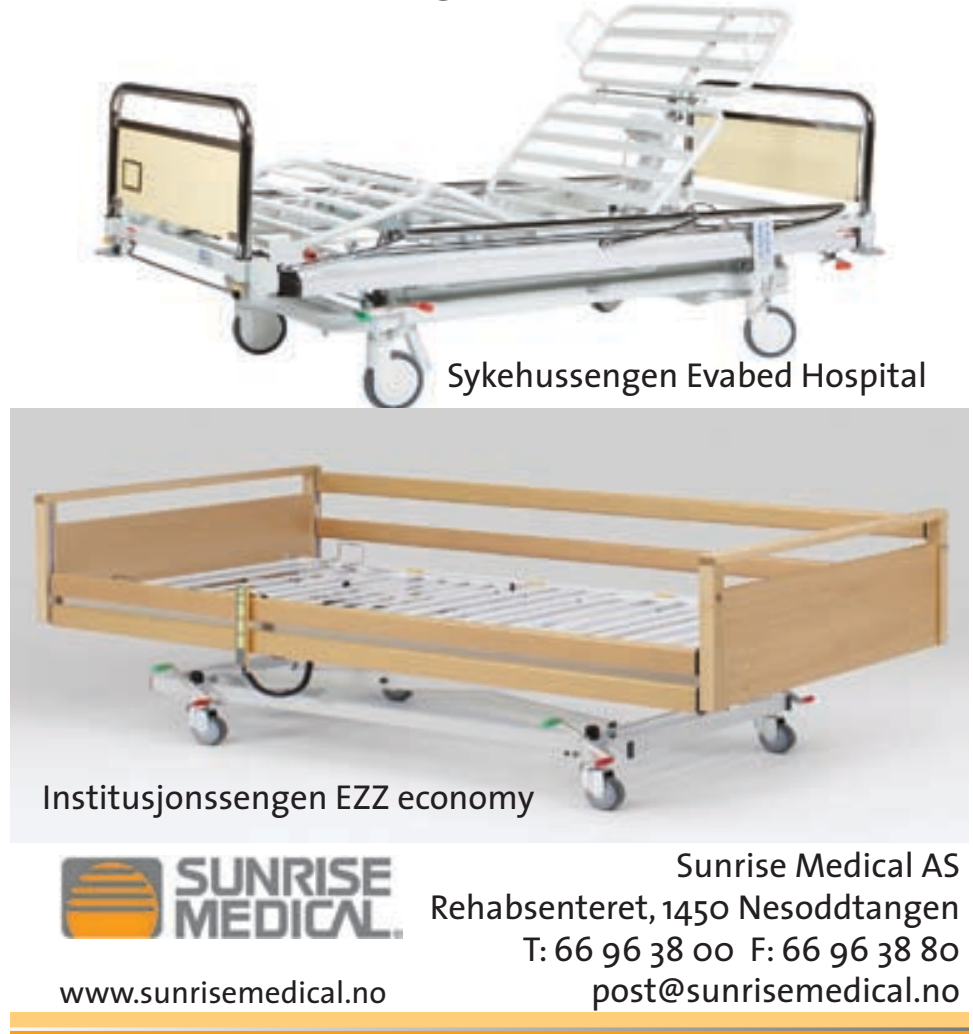

